\title{
Adam Phillips: On Wanting to Change
}

\author{
Penguin, 2021, 160 pp., ISBN: 978-0241291771
}

\author{
Paula Marantz Cohen ${ }^{1}$ \\ Published online: 7 June 2021 \\ (C) The Author(s), under exclusive licence to Springer Science+Business Media, LLC, part of Springer Nature 2021
}

On Wanting to Change was written before the COVID-19 pandemic, but it seems uniquely useful now, as we emerge from a traumatic year and are obliged to think deeply about our lives - to consider what we want to change both about ourselves and about our society. Adam Phillips, a British psychoanalyst and author of many books, draws on Freudian theory and extensive literary, theological, and philosophical reading to address how human beings respond to change.

The book, short but densely argued, is divided into four chapters, each of which deals with change from a somewhat different, if overlapping, perspective. The book's premise is that, while we change by necessity as a result of our biology and our presence in a changing world, our relationship to change is often fraught and resistant.

The central motif is the idea of conversion, a means by which we seek to control change or at least feel that we have controlled it. According to Phillips, to be converted-to a religion, an ideology, or any systematic way of being-is always an attempt to arrive at a new place of apparent stasis and closure. This is an illusory site of safety, destined to be eroded by natural forces or by our own unpredictable and unconscious urges and needs.

Phillips begins by discussing Freud's early work with hysterics, patients whose taboo desires or traumatic experiences had been converted into somatic symptoms. Freud conceived of psychoanalysis as uniquely designed to de-convert these symptoms: to reclaim the emotional energy that created them and redirect it to productive and creative ends. Phillips also draws on William James's American Pragmatism as supportive of Freud's ideas. Like Freud, Jamesian pragmatism opposes stasis and calls for an open, improvisational approach to life.

Paula Marantz Cohen cohenpm@drexel.edu

1 Pennoni Honors College, Drexel University, 3301 Arch Streets, Philadelphia, PA 19104, USA
In reading this book, one immediately tends to reframe Phillips's ideas. For example, Freud's psychoanalytic method, with its closed system of meanings and treatment protocols, can be viewed as a conversion experience in its own right. Similarly, William James wrote extensively on the need to create salutary habits, behaviors that can be viewed as smallscale conversions or benign somatic symptoms. Such counterexamples, however, underscore the elusive but profound nature of Phillips's subject. Most everything, taken in a certain light, has the potential to function as a conversion. The issue is one of degree and duration, not to mention the perspective of the subject. Phillips points out: "As often happens in psychoanalysis, people aren't cured, they just lose interest in their symptoms. Their preoccupations fade, and evolve" (p. 43). The key here is whether the faded preoccupations of the past are replaced by or evolve into new, crippling ones or whether the attitude toward change itself changes. Conversion, as Phillips says again and again, is a drive for closure, a resistance to contradiction that cannot ultimately be sustained but which we seek out of desperation: "People are prone to conversion experiences when they can no longer bear the complexity of their own minds" (p. 44). Conversion is antithetical to skepticism, ambivalence, and uncertainty.

At one point, Phillips extends his insights to Freud himself. To what extent was Freud's invention of psychoanalysis a kind of conversion out of Judaism into a science of his own making? And going beyond this singular question: What does it mean to be a converted Jew or, for that matter, an assimilated one? Phillips notes that conversion, by definition, is never complete; the old desires and patterns of behavior are reinscribed and thereby preserved and can be obvious to others, if not to oneself. This puts me in mind of the assimilation of German Jews prior to the Holocaust and the shock they experienced at finding that their assimilation was seen by the Nazis as fraudulent. Conversion to anything tends to appear suspect to those outside of it.

The discussion of Jews and conversion leads into the second chapter, which deals with two famous cases of religious 
conversion: Saul/Paul's on the road to Damascus and Augustine's as described in his Confessions. Paul's conversion from Judaism to Christianity is said to have happened suddenly, running counter to his original intention to proselytize against Christianity. And yet it is unclear whether Paul's conversion represented a break with his former beliefs or an extension of them. As Phillips puts it: "in conversion experiences there has to be something there to be converted; the new can only be made out of the old. And it may be that one of the ways the new makes a name for itself is through the rhetoric of hyperbole; great claims are made, but over time the past begins to show through" (p. 56).

But the narrative of conversion can also move in the other direction and seem to grow more extreme over time. If, in some cases, the past begins to "show through" (why else do theologians read the Old Testament as a typology for the New?), in others the break comes to seem more dramaticmore distinct and antithetical to what came before. This can be useful in establishing the new system in counterpoint to the old, even as it creates increasing division and enmity between old and new. Thus, the hyperbolic narrative of Paul's conversion - of a dramatic rupture with Judaism-served strategically in the establishment of the early Church.

In the case of Augustine, Phillips notes that this conversion was sought rather than sudden: a return to an essential self and to God; hence, the prodigal son parable is often applied to Augustine's story. In this section, Phillips argues that conversions are often not immediate - that they involve determination and work, making them a form of self-conditioning (akin, one could argue, to William James' recipe for the creation of habits).

The third chapter widens the lens to discuss political change and the tendency for those who seek social panaceas to reduplicate the forms that they overthrow or resist. Phillips draws on two thinkers to elucidate the issue of political conversion. The first, Etienne Balibar, a French political philosopher and author of Violence and Civility, sees violence as society's formative material, what sexuality is for Freud (though Freud also acknowledged violence as part of the death drive). Balibar is concerned with the way violence as the originating energy that powers revolutionary movement can be converted into a civil, that is, civilized, form. But just as for Freud, sexuality, repressed or displaced, is liable to return, so cruelty and violence threaten to erupt in civilized society. Adapting Balibar's ideas, Phillips understands communism and fascism as using violence to "convert" the threatening complexity of society into something closed, homogenous, and controlled. But where violence is used to control the threat of violence, it must continue to be exerted in order to preserve the state of repression that it has brought into being.

The second thinker that Phillips draws on in this chapter is Wendy Brown, another political philosopher whose Undoing the Demos is a critique of neoliberalism in terms similar to
Balibar's critique of fascism and communism. According to Brown, speech in the context of neoliberal reason takes on the qualities associated with capitalistic expansion: "it appreciates through calculated investment, and it advances the position of its bearer or owner" (p. 84). In this model, ideas become increasingly consolidated, and the vibrant mix of ideas that we associate with liberal democracy disappears. As Phillips puts it: "Democracy fails when it allows conversion experiences to enter the realm of politics. As though where there was or has been conversion, there should be ongoing conversation and argument. A conversion is a conversation that has ended. There are fewer rival claims to conciliate or, indeed, imagine"(p. 85). He concludes, after Brown, that the result of neoliberal reason - "this language of profitability and the market"- taken to its ultimate point means the end of liberal education. I was reminded of this recently when a friend told me that his daughter would not read books which questioned her progressive views. This young woman had gone to elite schools, traditionally the site of humanistic learning, but had been converted to a neoliberal ideology that brooked no contradiction.

In the last chapter, Phillips goes some way to helping us think about constructive change: an approach to life that counters the narrow essentialism of conversion. He sees a way out in the free association encouraged in psychoanalysis. He then connects this with the philosophy of pediatrician and psychoanalyst Donald Winnicott. Winnicott saw the destructive urge as centered in our "need to be believed," the mirror image of conversion. Both are predicated on essentialist, closed systems; both desire to control complexity, ambivalence, and contradiction. Winnicott's therapeutic antidote is "surprise," akin to Freud's free association. Both surprise and free association open us to the world rather than confine us within prescribed systems of our own or another's making. Winnicott's surprise put me in mind of the "wonder" that Milton ascribes to Adam and Eve in Paradise Lost before the Fall; that is, before they were "converted" to shame and self-absorption.

Phillips concludes with a discussion of conversion as imitation. We seek to become like someone else in whom we see the certainty that we lack. The ultimate example, of course, is Christ, the model that Christians seek to imitate to become their best or better selves. Phillips contrasts Christ with another, earlier figure from antiquity, Socrates, whose inspiration for philosophers like Montaigne, Nietzsche, and Foucault lies in his lack of clear outline for imitation. Socrates, says Phillips, challenges us to find our own way. "We have to be converted to wanting to be ourselves, and to imagining our selves as not simply and solely - as more than - our set of identifications." (p. 130).

Christ and Socrates provide a useful contrast, though some might find Christ less simply prescriptive and Socrates less open to self-fashioning than Phillips makes them out to be. 
Still, the point stands: we need to think less about modeling ourselves on others and more about how to live as ourselves, which is to say, be comfortable with change and make choices that are not imitative, that do not fall back into patterns already laid out for us by our parents, teachers, and religious or political leaders. This is precisely what psychoanalysis is supposed to help us do, if only we had the time and financial means (not to mention the help of a gifted analyst) to do it. The difficulty of using Phillips's book as a self-help guide in lieu of psychoanalytic treatment (which, on some level, it might seem to encourage us to do) does not prevent it from illuminating our desire for and difficulty with change.

Is it any wonder in the present moment, with so much uncertainty and fear around us, that we seek conversion experiences which promise clarity, justice, and safety? And yet, as Phillips points out, such efforts often entail violence and cruelty, and are likely to damage elements in our society that are central to democracy and to ourselves as individuals with unique wants and needs. Yet if the point is to avoid conversion at all costs, we must also ask what this avoidance may cost us. What can we truly accomplish if we do not allow ourselves to be converted to some prescribed set of ideas or beliefs? The answer to this question, as Phillips notes at one point, is the scientific concept of experiment. We can embrace a position that suits our temperament and conforms to what we know and want in the present moment but continue to experiment, be prepared for surprise, and be open to change.

Reviewer: Paula Marantz Cohen is Distinguished Professor of English at Drexel University, Philadelphia and the author of Of Human Kindness: What Shakespeare Teaches Us About Empathy (2021).

Email: cohenpm@drexel.edu

Publisher's Note Springer Nature remains neutral with regard to jurisdictional claims in published maps and institutional affiliations. 